\title{
Analytical studies to tracing the effects of ozone chemicals on an existing water treatment plant
}

\begin{abstract}
The quest to living and dining in a healthy environment do not only prolong the life of human being alone but the lives of all other important creative's around them. Human and industrial activities around the urban cities across the globe have continually posing treats to achieving the objective of a healthy living. This study is on tracing the effects of ozone chemicals on the Kaduna North Water Treatment Plant (KNWTP) and some selected points on the public consumption outlets. The qualitative analysis was done by comparing the laboratory results obtained with the acceptable value range of traced elements, $\mathrm{pH}$ and turbidity as in accordance with World Health Organization (WHO) standard. It was observed that many of the trace elements fall within the WHO standard with the exception of carbon (IV) dioxide $\left(\mathrm{CO}_{2}\right)$ concentration of the raw water and treated water of about $16.00 \mathrm{ml}$ and $12.00 \mathrm{ml}$ respectively, and that of Nitrite $\left(\mathrm{NO}_{3}\right)$ with concentration range of $0.25 \mathrm{~mol} /$ liter and $0.16 \mathrm{~mol} /$ liter respectively, in which both values fall above the required standard for drinking water of $9.50 \mathrm{ml}$ and $0.11 \mathrm{~mol} /$ liter respectively. In summary, the study shows that the activities and performance of KNWTP are relatively in good order.
\end{abstract}

Volume 3 Issue I - 2018

\author{
MN Idris,' S Babayo,' Al Ibafe ${ }^{2}$ \\ 'Department of Chemical Engineering University of Maiduguri, \\ Nigeria \\ ${ }^{2}$ Department of Chemical Engineering University of Benin, \\ Nigeria
}

\author{
Correspondence: MN Idris, Department of Chemical \\ Engineering University of Maiduguri, Nigeria Tel +234(0)705 \\ 877-1096, Email idrismn@hotmail.com \\ Received: June 16,2017 | Published: February 12, 2018
}

Keywords: analysis, ozone chemicals, water treatment, $\mathrm{CO}_{2}, \mathrm{NO}_{3}$

Abbreviations: $\mathrm{CCDC}$, canadian health laboratory centre for disease control; CDU, crude distillation unit; KNWTP, kaduna north water treatment plant; KSWBL, kaduna state water board laboratory; KRPC, kaduna refinery and petrochemical company; NIS, national institute for standards; VOCs, volatile organic compounds; WHO, world health organization

\section{Introduction}

Ozone is a colorless, pungent, highly reactive gas, considered as a secondary pollutant; it is not emitted into the air directly. It is composed of three oxygen atoms $\left(\mathrm{O}_{3}\right)$ and the principal component of smog, which is caused primarily by automobile emissions, predominantly in urban areas. Distinct from the stratospheric ozone layer, which lies 10 $\mathrm{km}$ above the earth's surface, the pollutant ozone is in the troposphere and is formed by photochemical reaction driven by the action of ultraviolet light on the precursor pollutants oxides of nitrogen (NOx), and volatile organic compounds (VOCs). Ozone concentrations in urban areas rise in the morning, peak in the afternoon, and decrease at night. The highest levels of ozone, as well the frequency of their recurrence dependence on the overall weather conditions, and occurs most frequently when atmospheric inversions trap the pollutants near the ground. ${ }^{1}$ Water purification is the process of removing undesirable chemicals, biological contaminants, suspended solids and gases from contaminated water. The goal is to produce water fit for a specific purpose. Most water disinfection for human consumption (drinking water), but water purification may also be designed for a variety of other purposes including fulfilling the requirement of medical and industrial applications. In this paper,

The aims and objectives are to,

i. Determine the possible source of ozone in the KNWTP process

ii. Estimate the various percentage of ozone chemical concentrations in all stages of the water treatment plant

iii. Determine the effect of ozone chemical at all stages of KNWTP.

\section{Problem statement}

Due to the increase in global population growth, human and industrial activities; use of automobiles and heavy engines without proper emissive controls has resulted to increase in ozone formation. The ozone $\left(\mathrm{O}_{3}\right)$ chemical has become a significant pollutant in all stages of water treatment, right from the source of raw water (intake) to the final stage (product) and the public consumers.

\section{Research justifications}

The justification of this work is on tracing the effect of ozone chemicals in the water will lead to production of good and quality water for both domestic (healthy) life and industrial purposes.

\section{Background and literature studies}

Ozone is an oxygen allotrope of which three atoms are bound together to form a molecule $\left(\mathrm{O}_{3}\right)$. It exists mostly in the stratosphere layer and in small amount in troposphere. ${ }^{2}$ Ozone in these layers formed through absorption of ultraviolet radiation by oxygen molecule in the air, which followed by the breaking of that molecule as radicals. The radical species join any intact oxygen molecule to form ozone. Ozone gas is a form of oxygen. It is a colorless, highly reactive gas that exists from the earth's surface miles up into the atmosphere. Ozone has three atoms of oxygen $\left(\mathrm{O}_{3}\right)$, whereas the oxygen molecule we need to breathe only has two atoms. It is the third atom that makes ozone a highly reactive gas. ${ }^{3}$

\section{Ozone chemistry}

Ozone $\left(\mathrm{O}_{3}\right)$ has become a significant pollutant as a result of increased population growth, industrial activities, and use of the automobile. It is a pollutant that is formed in the lower atmosphere (troposphere) from a complex series of sunlight-driven reactions between NOx, carbon monoxide (CO), volatile organic compounds (VOCs) which are largely hydrocarbons, and methane $\left(\mathrm{CH}_{4}\right)$. The primary source of NOx to the troposphere is fossil-fuel combustion. 
The difficulties to regulating $\mathrm{O}_{3}$ occurs in the regions of high NOx (primarily urban centres and power plant plumes), ozone formation is limited by the availability of hydrocarbons. In regions of low NOx (primarily rural areas with abundant emission of natural hydrocarbons), $\mathrm{O}_{3}$ formation is limited by the availability of $\mathrm{NOx}{ }^{4}$ Tropospheric ozone is an air pollutant that causes adverse human health impacts. Increasing industrialization without emissions controls will increase releases of chemical precursors to ozone, such as NOx and VOCs. Changes in climate, including increasing temperature and other changing meteorological variables, have a complex effect on ozone concentrations. Previous studies have explored the impacts of future emissions and climate on surface ozone concentrations using climate and Chemical transport models. ${ }^{5}$

\section{Ozone layer}

The ozone layer is known to be scattered between 19 and $30 \mathrm{~km}$ (12 to 30 miles) up in the Earth's atmosphere, in a region called the stratosphere. Ozone is created in the stratosphere when UV radiation from the Sun strikes molecules of $\mathrm{O}_{2}$ and causes the two oxygenatoms to split apart. If a freed atom bumps into another $\left(\mathrm{O}_{2}\right)$, it joins up, forming ozone $\left(\mathrm{O}_{3}\right)$. This process is known as photolysis. At different temperature and pressures (i.e. varying altitudes within the stratosphere), there are different formation and destruction rates. Ozone concentrations are highest between 19 and $23 \mathrm{~km}{ }^{6}$ The ozone dispersion layers are presented in Figure 1, Figure 2 below. The source reference is http,//int.search.tb.ask.com

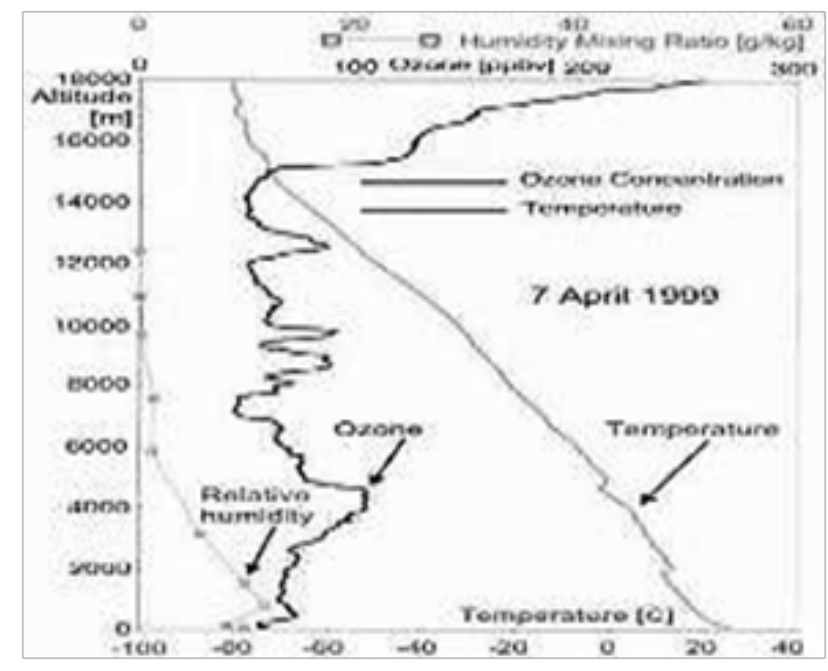

Figure I Profile on ozone dispersion layers.

\section{Ozone water intermolecular attraction}

Ozone, which is generated in the stratosphere, is well known to strongly absorb solar radiation in the ultraviolet (UV) region and contribute to the radiative forcing of the atmosphere that influencing climate. Tropospheric ozone can be produced photo-chemically in situ or transported down from the stratosphere. Tropospheric ozone exhibits significant radioactive forcing, because $\left(\mathrm{O}_{3}\right)$ is a greenhouse gas, but it also acts as a pollutant; its concentration is one of the measures to indicate the air quality worldwide. ${ }^{7}$ The implications of the ozone spectral changes in terms of atmospheric $\mathrm{OH}$ production rates are evaluated and lead us to the conclusion that the photochemistry on clouds constitutes an additional source of $\mathrm{OH}$ radicals in the troposphere. ${ }^{8}$

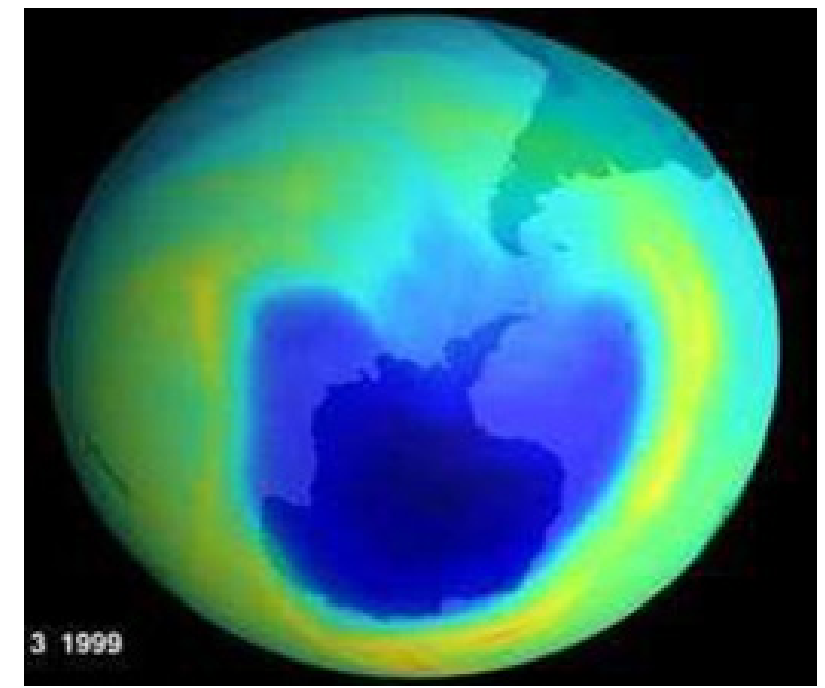

Figure 2 Ozone 3D dispersion layers.

\section{The world health organization (WHO)}

The WHO has major functions to propose regulations, guidelines, and recommendations in order to realize human right to have access. There are certain problems in water treatment which are either a chemical or biological order that prove particularly difficult to correct. Some of these relate primarily to surface waters, although they can also affect ground water. Dissolved aluminium is rarely found in excessive quantities in raw water. Higher aluminium concentrations are sometimes found in waters that have undergone treatment using an aluminums salt where the flocculation $\mathrm{pH}$ has not been accurately controlled (between 6.0 and 7.2). This problem can be avoided by accurately controlling the $\mathrm{pH}$ valve (i.e., the $\mathrm{pH}$ adjustment chemical must be added with the coagulant) or by replacing the aluminium sulphate with ferric chloride or polymers. ${ }^{9}$

\section{Water pollution}

Water pollution occurs when a body of water is adversely affected due to the addition of large amounts of chemical and polluted materials substance to the water. The sources of water pollution are categorized as being a point source or a non-source point of pollution. Point sources of pollution occur when the polluting substance is emitted directly into the waterway. For instance, a pipe spewing toxic chemicals directly into a river is a good example. A non- point source occurs when there is runoff of pollutants into a waterway, when fertilizer from a field is carried into a stream by surface runoff. ${ }^{10}$ The various types of water pollution are, toxic, organic, thermal and ecological pollution. Table 1 represents the WHO values for drinking water constituents and characteristics, as reported by. ${ }^{11}$

\section{History and process operations of the KNWTP}

KNWTP was commissioned for operation in the year 1972. This was able to sustain water supply to the major parts of Kaduna state. Initially the daily production is was 40 million liters per day (MLD), and debottlenecked to 90 MLD due to population increase. In 1980, a new plant was constructed having a capacity of 150 MLD. The KNWTP is situated along the Federal Government College (FGC), Malali off-Rabah road, Kaduna. The plant was designed to treat raw water from river Kaduna which is situated at about half- kilometer to 
the treatment plant through underground pipes. The plants (old and new) have a total capacity of treating about $3,100 \mathrm{~m}^{3}$ of water daily which was constructed by metallurgical construction company of China. The treatment plant comprises of units such as, the laboratory (quality assurance), raw water inlet channel, clarifiers (clarification units), ground reservoirs, treated water, treatment water pumping station, and chemical dosing plant.

Table I Water Quality Criteria for Drinking

\begin{tabular}{|c|c|c|c|c|}
\hline S/No. & Parameter & Unit & $\begin{array}{l}\text { Highest desirable } \\
\text { level }\end{array}$ & $\begin{array}{l}\text { Maximum possible } \\
\text { level }\end{array}$ \\
\hline I & $\mathrm{pH}$ & $1-14$ & $7.0-8.5$ & $6.5-9.2$ \\
\hline 2 & Color & Alpha & 15 & 50 \\
\hline 3 & Turbidity & FTU & 5 & 25 \\
\hline 4 & Dissolved Oxygen & $\mathrm{mgL}^{-1}$ & 7.5 & - \\
\hline 5 & Conductivity $(\mathrm{NaCl})$ & $\mathrm{mgL}^{-1}$ & 40 & - \\
\hline 6 & Total Solids & $\mathrm{mgL}^{-1}$ & 500 & 1500 \\
\hline 7 & Silica & $\mathrm{mgL}^{-1}$ & - & 40 \\
\hline 8 & Sulphate & $\mathrm{mgL}^{-1}$ & 200 & 400 \\
\hline 9 & Chlorine & $\mathrm{mgL}^{-1}$ & 0.2 & 1 \\
\hline 10 & Chloride $(\mathrm{NaCl})$ & $\mathrm{mgL}^{-1}$ & 200 & 600 \\
\hline II & Ammonia $\left(\mathrm{NH}_{3}\right)$ & $\mathrm{mgL}^{-1}$ & 0.05 & 0.2 \\
\hline 12 & Nitrate & $\mathrm{mgL}^{-1}$ & 5.6 & 11.3 \\
\hline 13 & Nitrite & $\mathrm{mgL}^{-1}$ & - & 0.1 \\
\hline 14 & Hardness & $\mathrm{mgL}^{-1}$ & 150 & 200 \\
\hline 15 & Alkalinity & $\mathrm{mgL}^{-1}$ & - & 150 \\
\hline 16 & Iron & $\mathrm{mgL}^{-1}$ & 0.1 & 1 \\
\hline 17 & Manganese & $\mathrm{mgL}^{-1}$ & 0.05 & 0.5 \\
\hline 18 & Magnesium & $\mathrm{mgL}^{-1}$ & 30 & 150 \\
\hline 19 & Copper & $\mathrm{mgL}^{-1}$ & 0.05 & 0.1 \\
\hline
\end{tabular}

Source: Environmental Protection Agency, Drinking Water Treatment, United States of America EPA (2004).

The objectives of KNWTP are,

i. To meet up with the WHO standard

ii. To be able to determine the volume of water been process per day and

iii. To pave ways for proper disinfection of treated water for free and safe consumption by the public 12 .

Stages of water treatment plant (Kaduna North): The nature of water treatment depends on the kind of impurities the water contains. Surface water is likely to be dangerously contaminated and turbid. Some surface water contain large particles of organic matter, others are dirty brown in colour and may contain a lot of bacteria, while some are free from both large number of bacteria and dirty colour. However, irrespective of either the amount of bacteria or turbidity, the KNWTP Malali does carry out their daily treatment. This is a verified statement during the course of this research studies.

The Malali water works is made up of two plants which are old and the new plant. The old plant is made up of five units which are the; abstraction unit (water intake), the pre-settling unit, the clarifying unit, filtration unit and the storage unit. While the new plant is made up of the raw water intake unit, balancing tank, chemical preparation unit, mixing chamber (flow division chamber), clarifying unit, filtration unit, disinfection unit, storage unit and distribution unit. All these units are connected to one another. The raw water flows from river Kaduna by gravity to an alteration water intake structure. The processes are; water intake, screening, aeration, mixing (pre-chlorination), coagulation, flocculation, settling, filtration, disinfection, storage and distribution. ${ }^{12}$

Water intake section: The intake section is located at the river bank where the treatment process begins. Raw water is pumped directly from the river by the help of centrifugal pumps which are submersible, into the balancing tank. There are six pumps at the intake; pumps 1, 2 and 3 have the total capacity of 2,084 liters/hr, while pump 4 has capacity of 3,550 liters/hr, pumps 5 and 6 have the capacity of 3,331 liters/hr. There are also screen bars which block debris and other larger objects from passing through the pumps. The tower can also be called low lift. ${ }^{12}$ The raw water was then subjected to screening, chemical pre-treatment and pre-sedimentation processes. 
Aeration: Aeration (also called aerification) is the process by which air is circulated through, mixed with or dissolved in water. This takes place at the balancing tank. The tank is an open tank whereby air circulates through the water thereby removing some certain odor, oxides, iron and manganese salts and to increase the oxygen content of the water 13 as referred in (Figure 2).

Pre-chlorination: This is the addition of chlorine to raw water in the mixing chamber for the purpose of disinfection, taste and odor control, iron and manganese removal, and to remove some gases such as $\mathrm{NH}_{3}$ and $\mathrm{HS}$ that may be present in the raw water. It also aid in coagulation, controlling algae problems in basins. In addition, the chlorine has a much longer contact time when added at the beginning of the treatment process, so pre-chlorination increases safety in disinfecting heavily contaminated water as in Figure 3. It helps to keep the clarifiers clean and prevents sludge within these clarifiers. A small amount of free chlorine must remain in the raw water to ensure that pre-chlorination is active. ${ }^{10}$

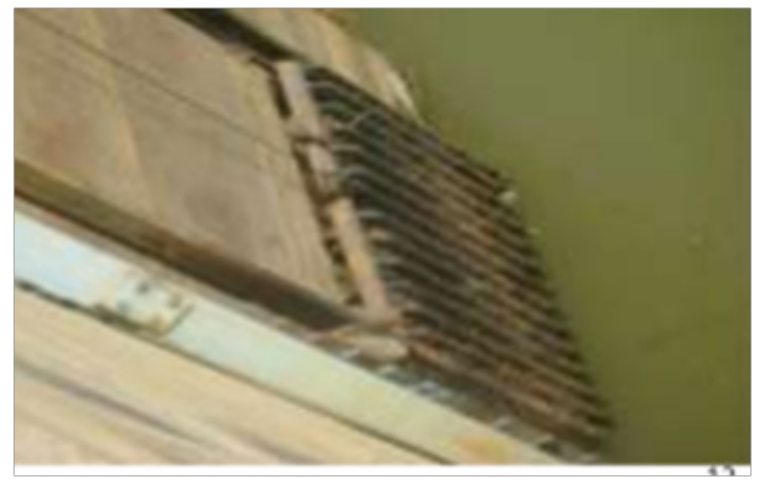

Figure 3 Screen bars of the intake section.

Mixing: This is a process of reaching water with chemicals. The coagulants prepared in the chemical building are then injected to the mixing chamber where it will be properly mixed with the raw water from the balancing tank. This kind of mixing is called flash mixing. Flash mixing is the even distribution of the flocculants throughout the volume of water in less than a second. (Figure 4) depicts the flow division chamber. The lime slurry is also injected to the mixing chamber and this is called pre-liming. The purpose of adding lime is to adjust the $\mathrm{pH}$ of the raw water and the alum is added to the raw water for the purpose of coagulation of dissolved or suspended colloids or particles present in the raw water. The formation of this flux is as a result of the addition of alum and it is known as flocculation and hence the solution no longer remains pure raw but now called flux water. ${ }^{13}$

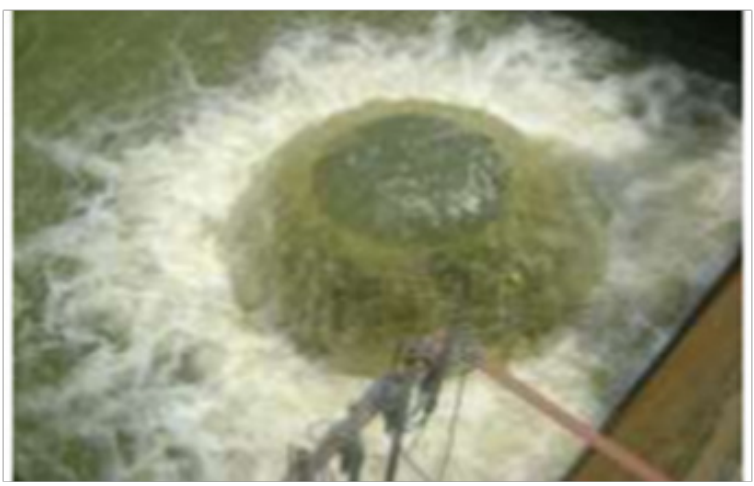

Figure 4 Balancing tank of KNWTP.
Sedimentation/settling: Figure 5 represents the sedimentation basin. Once the flocs are satisfactorily formed, the water then flows to the sedimentation tank where the flocs settle at the bottom of the tank and the clear water remains at the top. There are structures at the bottom of the clarifiers which are called sludge blanket where sludge is formed. The accumulation of flocs at the bottom of the sedimentation tank is called sludge formation. The addition of new flocculated sludge tends to increase the volume of the sludge in the blanket which flows over into the concentrators. Sludge is drawn off on an intermittent basis from these concentrators. ${ }^{13}$

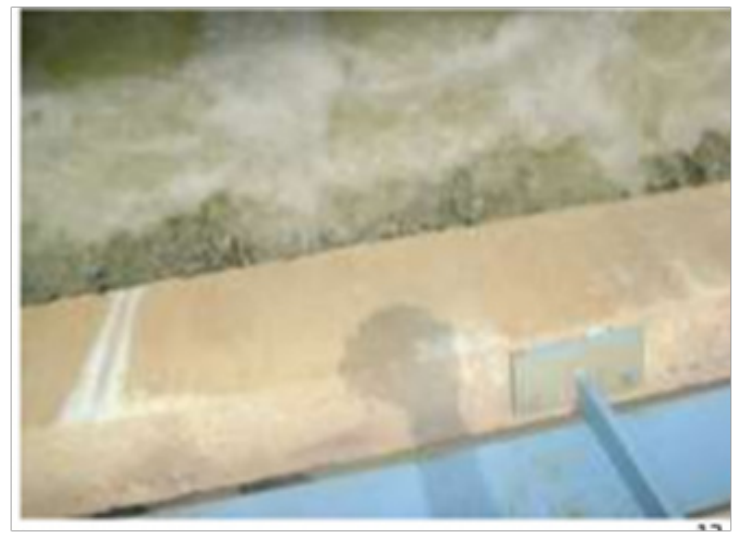

Figure 5 Flow division chamber of KNWTP.

Filtration: Figure 6 represents the filter galleries of the KNWTP. Filtration is the process whereby water in the basin is filtered by passing through different layers of sand bed enclosed in a tank called filters. After separating most floc, the water is filtered as the final step to remove remaining suspended particles and unsettled floc. The purpose of filtration is to remove suspended matter from water. The most common type of filter is a rapid gravity sand filter. Water moves vertically through the three layers of the media. Most particles pass through surface layers but are trapped in pore spaces or adhere to sand particles. Effective filtration extends into the depth of the filter. When the water passes through the filter bed; the filtered water is recovered through the filter nozzles which are fitted at the bottom of the filters, which is beneath the last layer of the sand bed (Figure 7). The filtered water then pass through the filter galleries to the reservoir tank. ${ }^{15}$

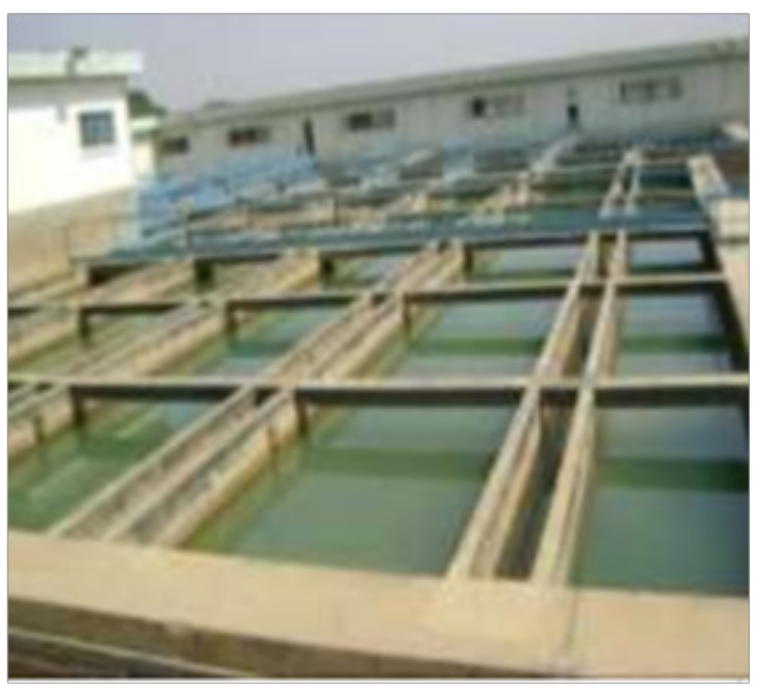

Figure 6 Sedimentation basin KNWTP. 


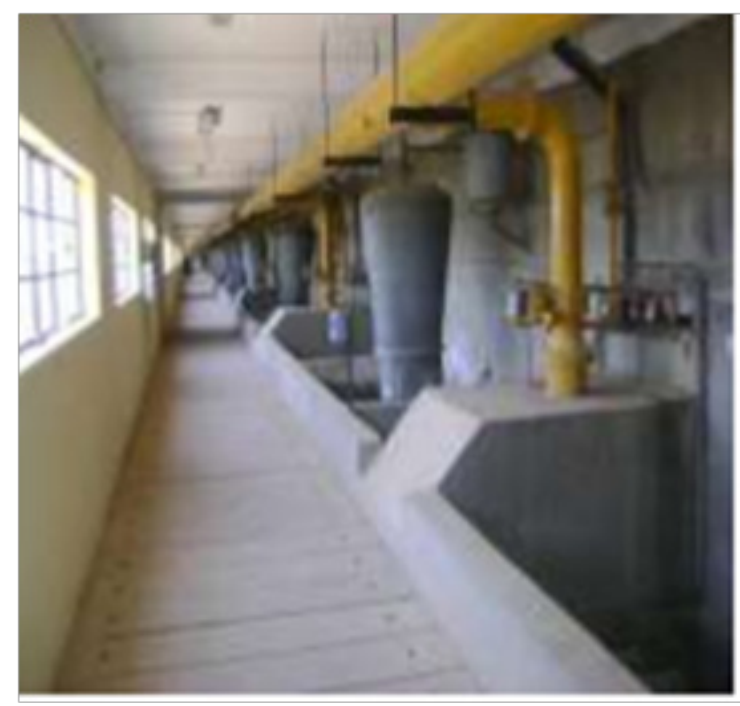

Figure 7 Filters galleries of the KNWTP.

Disinfection: Disinfection is accomplished both by filtering out harmful micro-organisms and also by adding disinfectant chemicals. Water is disinfected to kill any pathogens which pass through the filters and to provide a residual dose of disinfectant to kill or inactivate potentially harmful micro-organisms in the storage and distribution systems. Possible pathogens include viruses, bacteria and other organisms. The most common disinfection method involves some form of chlorine or its compounds such as chloramine or chlorine dioxide. This process is also called post-chlorination. Chlorine plays an important role in the last stage of the treatment process because; it helps in destroying the micro-organisms which are dangerous to human health. ${ }^{13}$

\section{Effects of ozone chemicals in water treatment plant}

The Effects of ozone on corrosion: There are some ambiguities on the literature concerning the effects of ozone on the corrosion behavior of metals and alloys of water works. This is true, where low dissolved ozone concentrations have been investigated. Some investigations show increased corrosion of e.g. carbon steels, brasses, nickel-alloys and stainless steels in ozonized waters, but others indicate either decreased or neutral effects. Most often these investigations concern environments in water purification of fresh water or in cooling waters (with and without chlorides), where the ozone concentrations are low and the service conditions have sometimes been poorly defined. ${ }^{15-17}$ The decomposition mechanism of ozone in aqueous solutions is a matter of uncertainty. Views on the mechanism differ widely, because of the variety of the ways in which decomposition can take place under different conditions. ${ }^{18}$ Most often the overall stoichiometry can be explained by Eqn (1) as represented from. ${ }^{19,20}$ Depending on the $\mathrm{pH}$ of the solution in which it is dissolved, molecular ozone will either react directly with components in solutions or decompose into hydroxyl radical, oxygen and hydroxide. At $\mathrm{pH}$ values above 7.5 , the decomposition of ozone to hydroxyl radicals increases. Below this $\mathrm{pH}$ value molecular ozone is stabilized and only a small fraction converts to radicals.

$$
2 \mathrm{O}_{3}+\mathrm{H}_{2} \mathrm{O}+e^{-} \rightarrow \mathrm{OH}+5 / 2 \mathrm{O}_{2}+\mathrm{OH}^{-}
$$

Dissolved ozone increases corrosion rates for carbon steels and low alloyed steels in aqueous solutions. In deionized water where the corrosion rate (in stagnant and slow flow rates) is about 2 or 3 times higher in the presence of $2.10 \mathrm{mg} / 1$ ozone than in the absence of ozone..$^{21}$ According to ${ }^{22-28}$ dissolved ozone concentrations $0-7 \mathrm{mg} / \mathrm{l}$ have no effect on the corrosion rate of stainless steels in deionized water and corrosion rates in immersion tests are low. ${ }^{22}$

Table 2 Apparatus used at KNWTP laboratory

\begin{tabular}{|c|c|c|c|c|}
\hline \multirow[t]{2}{*}{ S/No } & \multirow[t]{2}{*}{ Apparatus } & \multicolumn{2}{|c|}{ Capacity and size of the equipment } & \multirow[t]{2}{*}{ Manufacturer } \\
\hline & & $\begin{array}{l}\text { Capacityl } \\
\text { Concentration }\end{array}$ & $\begin{array}{l}\text { Number and } \\
\text { size }\end{array}$ & \\
\hline 1 & $\begin{array}{l}\text { Water Sample } \\
\text { Burette }\end{array}$ & $420 \mathrm{ml}$ at $0.50 \mathrm{M}$ per liter & I & $\begin{array}{l}\text { Popular science Apparatus workshop PVT. Ltd. Ambala, } \\
\text { Haryana }\end{array}$ \\
\hline 2 & Tripod stand & - & 5 & “ \\
\hline 3 & Conical flask & 250 & 10 & $"$ \\
\hline 4 & Pipette & I & $3.5 \mathrm{ml}$ & 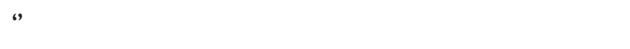 \\
\hline 5 & Measuring cylinder & 3 & $500 \mathrm{ml}$ & $"$ \\
\hline 6 & Beaker pipette filter & 2 & 250 & \\
\hline
\end{tabular}

Conversion Factor of Conductivity $(\mathrm{NaCl})$ to $\mathrm{EC}(\mu \mathrm{S} / \mathrm{cm})$ at $25^{\circ} \mathrm{C}$, Sodium chloride, $1 \mathrm{~mol} /$ litre is $85 \mathrm{mS} / \mathrm{cm}$

The cyanide $\mathrm{CN}$-, thiocyanate $\mathrm{SCN}^{-}$and fluoride $\mathrm{F}$ - measurements, Thiocyanate (SCN-), normally present in low concentrations in body fluids, is the major metabolic product of cyanide (CN-). In fact, cyanide released gradually from its combination with ferric ion of the cytochrome oxidase, is metabolized to thiocyanate after reacting with a sulphur donor, such as thiosulfate.

Health effect of ozone in water: Ozone can be toxic not only for microorganisms, but for humans as well. To humans, Ozone is an irritant to the eyes, nasal passages and respiratory system. Ozone chemical must be carefully handled because it may cause acute health effects and can be fatal at concentrations as low as 1000 ppm. In drinking water, the concentration of chlorine is usually very low and is thus not a concern in acute exposure. More of a concern is the long term risk of cancer due to ozonic exposure to ozonated water. This is mainly due to the trihalomethanes and other disinfection byproducts, which are by-products of ozonation. Trihalomethanes are carcinogens, and have been the topic of concern in ozonated drinking water. Ozonated water has been associated with increased risk of bladder, colon and rectal cancer. In the case of bladder cancer, the risk 
may be doubled. There are concerns about carcinogens in drinking water. The Canadian Health Laboratory Centre for Disease Control (CCDC) says that the benefits of ozonated water in controlling infectious diseases outweigh the risks associated with ozonation and would not be enough to justify its discontinuation. ${ }^{23,24}$ Ozone irritates the eyes, upper respiratory tract and the lungs. Many people exposed to airborne concentrations of ozone above $0.1 \mathrm{ppm}$ may develop a headache, although for few minutes. The onset of pulmonary edema (fluid buildup in the lungs) may be delayed in few hours after exposure to concentration above $1.5 \mathrm{ppm}$. Long term exposure to ozone at concentration above $0.1 \mathrm{ppm}$, or a single high exposure, may lead to some reduction in lung function. There is also some evidence that the oxidizing effect of ozone could lead to premature aging of the body as a whole. Medical studies show no evidence of ozone causing cancer or lung allergies, or harming a Festus..$^{25}$

\section{Various source of ozone to KNWTP}

The quality of water is affected by the composition of the atmosphere. The addition of pollutants created from various human activities gradually contributes to the deterioration of water quality. The study of surface ozone (ozone produced near the ground where people breathe the air) and using ozone sensitive plants as bioindicators of ozone induced plant injury will help develop an understanding of how human behavior affects the quality of water and an awareness of its environmental impact. ${ }^{26,27}$

Automobiles, trucks, buses and airplanes: Human activity has added new concentrations of pollutants to the water. The major contributors are vehicles (automobiles, trucks, buses and airplanes) and industrial burning of fossil fuels (as oil and coal burning utility plants). The primary gases that contribute to the production of surface ozone are exhausts from any internal combustion gasolinefueled engine. The major by-products of the combustion process are, carbon monoxide (CO), nitrogen oxides (NO), and partially burned hydrocarbons called volatile organic compounds (VOCs) that are very reactive. ${ }^{28,29}$ A good example is clearly represented in (Figure 6). Hydrocarbons are also a byproduct whenever things are burned. For example, a forest fire produces hydrocarbons, which are molecules of carbon and hydrogen. But these are far-less reactive and of lesser importance to the formation ozone than are the VOC's emitted within industrial and auto transportation exhausts. ${ }^{30}$

Kaduna refinery and petrochemical company (KRPC) as a source of ozone generation to the KNWTP: The flare system in KRPC consists of two elevated flares; the operating flare and the emergency flare in order to dispose released gases from process units. The total amount of released gases or vapour to the flare system is about 570 ton $/ \mathrm{h}$. The relieving gas distribution is approximately $20 \%$ to the operating flare stack and $80 \%$ to the emergency flare stack. The total steam supply to the system are be limited to $25 \%$ ton/h or less in order not to disturb the steam balance in the refinery. Both flare tips are designed to burn $20 \%$ of the design flaring load without smoke under the presence of sufficient injection steam. The flare system serves a very important purpose in the production department of the refinery and has to be kept under good condition. ${ }^{31}$ The flare has a small flame (perhaps the pilot flame or a small gas leak within the refinery). Flaring constitutes a hazard to human health, and is a contributor to the world-wide anthropogenic emissions of carbon dioxide which lead to ozone generation in stratosphere. For example, oil refinery flare stack may emit methane and other volatile organic compounds as well as sulfur dioxide and other sulfur compounds which are known to exacerbate asthma and other respiratory problems. Other emissions include; aromatic hydrocarbons (benzene, toluene and xylene) and benzapyrene which are known to be carcinogenic. ${ }^{32}$

\section{Materials and methodology}

\section{Materials and reagents}

Table 3 the summary of the laboratory apparatus used in this research studies at KNWTP laboratory.

Table 3 Qualitative analysis test for total hardness

\begin{tabular}{llll}
\hline Sample and reagent & Quality & \multicolumn{2}{c}{ Qualitative analysis } \\
\hline Sample water $(\mathrm{ml})$ & 50 & Raw water & Treated water \\
Butter Solution $(\mathrm{ml})$ & $\mathrm{I}$ & $\mathrm{I}$ & 38 \\
EDTA (mol/liter) & $0.0 \mathrm{I}$ & - & $\mathrm{I}$ \\
\hline
\end{tabular}

\section{Instrumentations and equipments}

(Figures 7-12) outline the pictures of some instrument and equipments used in this work which was carried out at the Kaduna State Water Board laboratory (KSWB LAB) on February 8, 2016 at about 09,00am - 15,00pm.

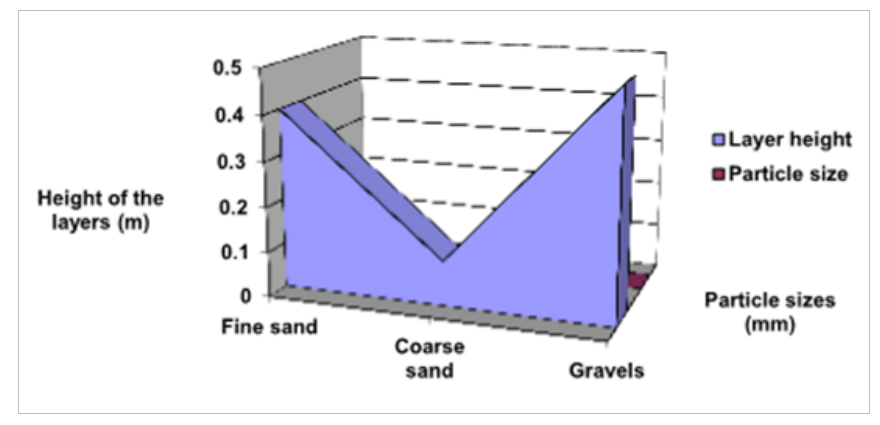

Figure 8 Schematic illustrations of sand layers.

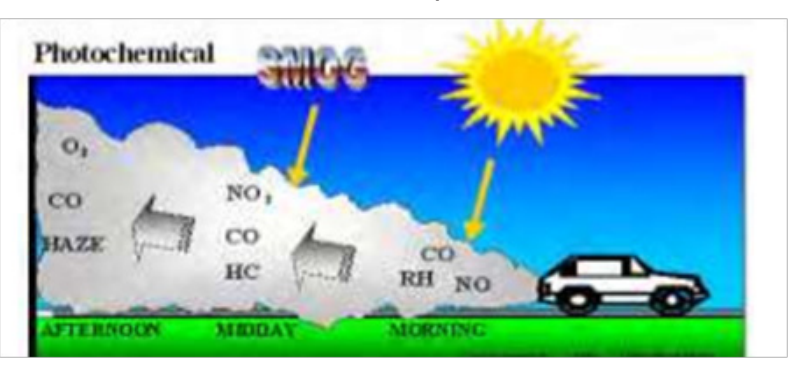

Figure 9 Emission effect of human activities on ozone layer.

\section{Experimental methodology}

Test for total hardness: When water pass through or over deposit such as limestone, the level of $\mathrm{Ca}_{2}^{+} \mathrm{Mg}^{+}$, and $\mathrm{HCO}_{3}$ ions present in the water would increase and cause water to be classified as hard water. Calcium hardness is caused by the present of calcium ion in the water. Calcium salts can be readily precipitated from water and high levels of calcium hardness tend to promote scale formation in water system. The test is therefore necessary to know the amount of $\mathrm{Ca}_{2}^{+}$, so as to make use of this formula 
Total hard=Calcium hardness + Magnesium hardness

Therefore this test is necessary to know how hard the water is for appropriate treatment in plant.

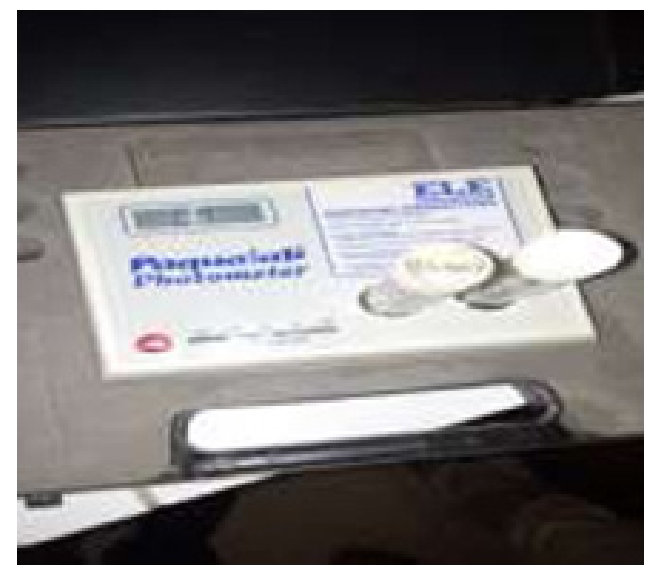

Figure 10 Paqualab Photometer

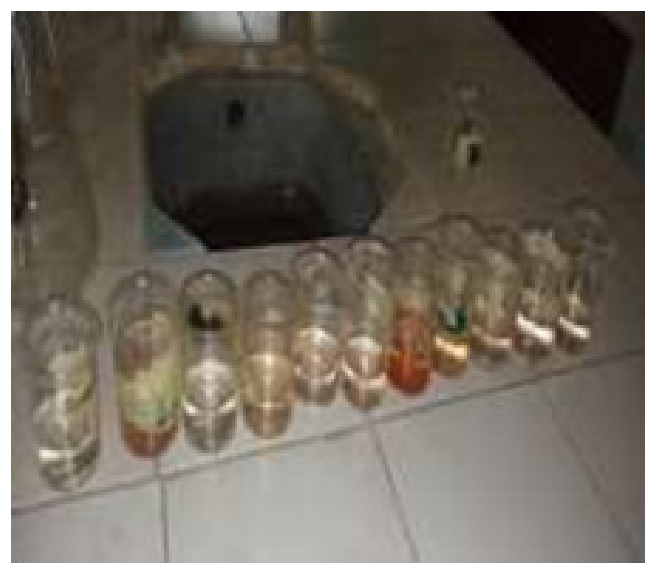

Figure II Sample for tests.

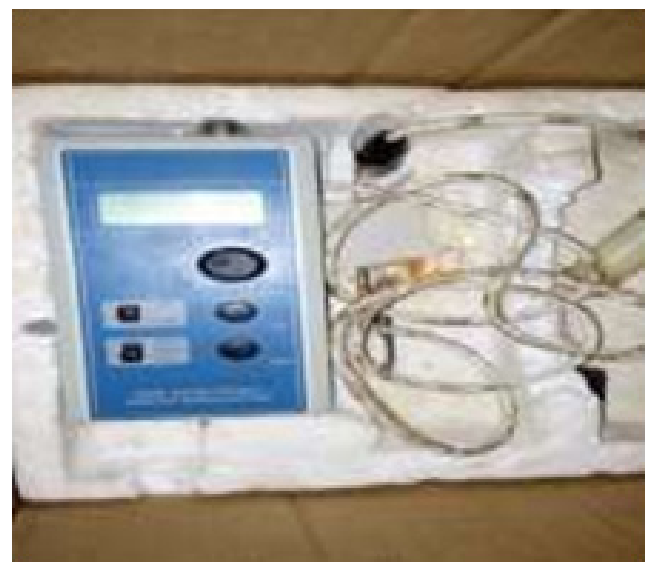

Figure 12 Turbidity meter.

Procedure: To $50 \mathrm{ml}$ of sample water, $1 \mathrm{ml}$ of buffer solution and Erichrome black indicator was added. The solution was titrated against $0.01 \mathrm{ml}$ of EDTA $\left(\mathrm{C}_{10} \mathrm{H}_{16} \mathrm{~N}_{2} \mathrm{O}_{8}\right)$ solution in drops. For calcium test 50 $\mathrm{ml}$ of water sample, $1 \mathrm{M} \mathrm{NaOH}$ solution and muroxide indicator was also added. The solution was titrated against $0.1 \mathrm{M}$ EDTA solution.
Observation: After titration, if the water is truly hard the colour will change from purple to blue indicating that the water is hard, but if no colour change water is not hard. For calcium test, after titration if $\mathrm{Ca}_{2}+$ ion is present in the water colour change from salmon pink to Purple indicating that $\mathrm{Ca}_{2}{ }^{+}$is present, but if not it would have remain pink

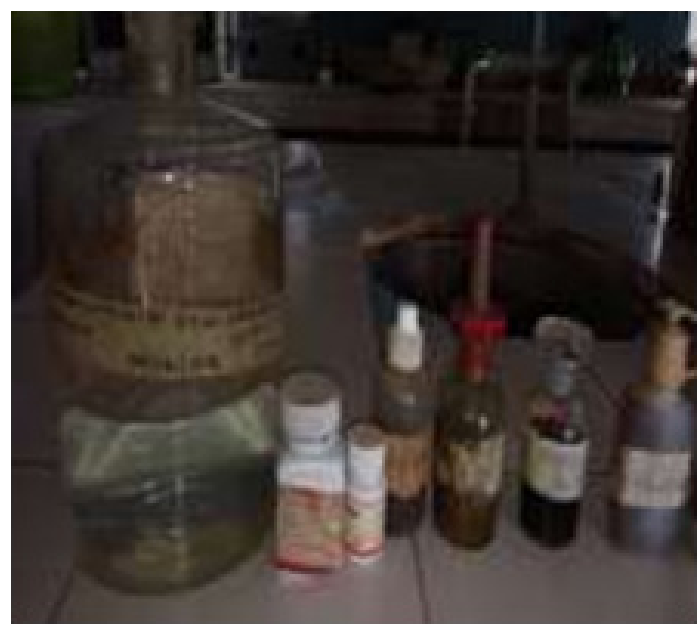

Figure 13 Reagent and indicators

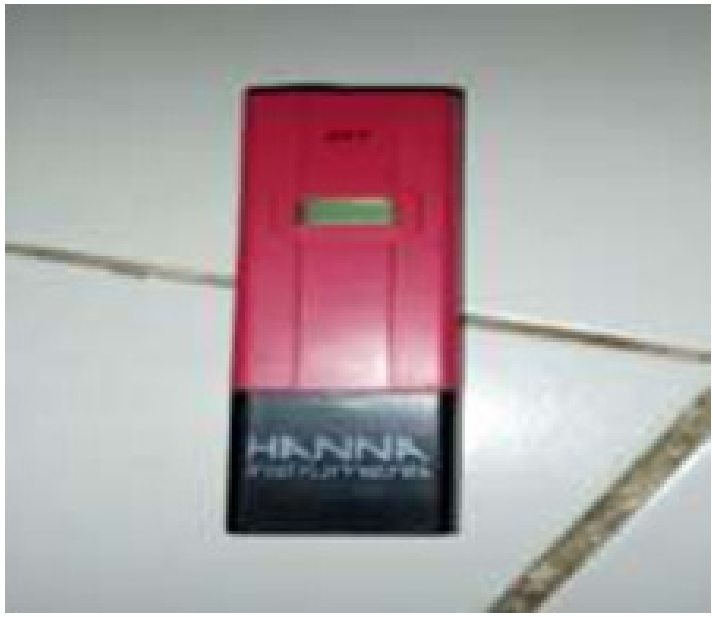

Figure 14 Reagent and indicators

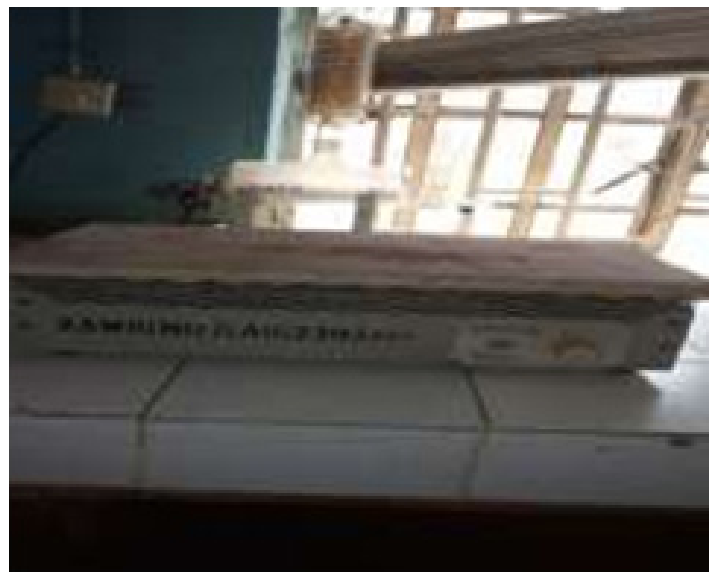

Figure 15 Hotman plate and distillatory. 


\section{Tests for total alkalinity}

Total alkalinity is an important test in determining the aggressiveness or scale forming tendency of the water. If the total alkalinity is low the water may be aggressive and cause corrosion to pipe work and structure; if the alkalinity is high the water may more produce scale formation. Alkalinity control is there for an important of many water treatment processes.

Procedure, To $50 \mathrm{ml}$ of the water sample, 3 drops of mixed indicator was added and the solution was titrated against $0.1 \mathrm{M} \mathrm{H}_{2} \mathrm{SO}_{4}$.

Observation, After titration if the colour changes from blue to golden yellow, it indicate that the water is corrosive due to the presence either Hydroxide, Carbonate, or bicarbonate ions.

\section{Tests for chloride}

Chlorine and chlorine-release compound are widely used for the disinfection of drinking water and swimming pool, for the control of micro-biological growth in cooling water, and in many other water treatment system. Accurate measurement of the chlorine residual is an essential aspect of the control of this chlorination process.

Procedure: To $50 \mathrm{ml}$ of the water sample was poured in to a conical flask and was mixed with 3 drops of $0.05 \mathrm{M}$ Potassium dichromate $\left(\mathrm{K}_{2} \mathrm{Cr}_{2} \mathrm{O}_{7}\right)$ indicator. The solution was titrated against Standard $0.1 \mathrm{M}$ $\mathrm{AgNO}_{3}$.

\section{Tests for carbon (IV) oxide}

This is the first test to be conducted in any given water, so as to avoid escaping of the $\mathrm{CO}_{2}$. $\mathrm{CO}_{2}$ can exist in water with $\mathrm{PH}$ values of 3.6 to 8.4 , but will never be present in water having a $\mathrm{pH} 8.5$ above. The test aim is to know the $\mathrm{CO}_{2}$ present in the water before sending to the plant for treatment.

Procedure, To $50 \mathrm{ml}$ of the water sample was poured in to a conical flask and was mixed with 3 drops of phenolphthalein indicator. The solution was titrated against $0.1 \mathrm{M} \mathrm{NaOH}$.

\section{Observation}

After titration, if the water changes from colorless to pink, it indicates that $\mathrm{CO}_{2}$ is present in the water sample.

\section{Tests for nitrate}

Nitrates are normally present in natural drinking and waste water. Nitrate enters the surface water supply from the breakdown of natural vegetation, the use of fertilizer modern agriculture and from the oxidation of Nitrogen compound in industrial process which make the water unsafe for drinking. So the test for it is very important, so as to determine if the water sample contain nitrite and the amount of it concentration present in the water.

Procedure, $20 \mathrm{ml}$ of water sample was poured in to test tube and 1 tablet of nitrate test and 1 mine spoon of nitrate powder was poured into the test tube and mixed, and the mixture was shaken thoroughly until the tablet dissolve completely, then $10 \mathrm{ml}$ of the dissolve solution was taken and one tablet of nitrate test was added in to the solution again and was mixed, After which a blank sample of $20 \mathrm{ml}$ of distilled was prepared and one of the test tube (Photometer test tube) was filled with the test sample and the other with the blank distilled water. The exterior of the tube was cleaned with a tissue paper and the tube is placed in the beam of the photometer and the reading was taken using the nitrite table.

\section{Test for iron}

Iron occurs in nature and is found in many natural and treated water. The presence of iron affects the test of beverages and causes unsightly staining of laundered clothes, plumbing swimming pool surface and lake. So the test for iron is necessary for these problems.

Procedure: $50 \mathrm{ml}$ of water sample was poured into a beaker and $2 \mathrm{ml}$ of concentrated Hydrochloric acid $(\mathrm{HCl})$ and $1 \mathrm{ml}$ of hydroxylamine was added to the water sample. The solution mixture was left to evaporate to half its original volume in the heating mantle then it was removed and allow to cool. Then $10 \mathrm{ml}$ of ammonia acetate and $2 \mathrm{ml}$ of phenanthroline was added to the mixture solution. Then the mixture was left to some time (10 minute) for color development. Then $10 \mathrm{ml}$ of distilled water was poured in to photometer test tube and the other with the mixture, the wavelength of the photometer was set to, and the reading was taking and trace on iron table.

Tests for sulphate: Sulphate occurs naturally in water. Sulphates are introduced into treated water by the use of chemicals such as aluminum sulphate. The presence of high level of sulphate is undesirable as the sulphate reduce bacteria generate sulphate that cause pitting of the metal surface. The range of sulphate ranges from $0-200 \mathrm{mg} / 1$.

Procedure: To $50 \mathrm{ml}$ of the water sample is poured into beaker, $1 \mathrm{ml}$ of concentrated $\mathrm{HCl}$ and $1 \mathrm{ml}$ of $0.05 \mathrm{M}$ barium chloride $\left(\mathrm{BaCl}_{2}\right)$ was added to the water sample, the mixed was allow to settle for $10 \mathrm{~min}$, then $10 \mathrm{ml}$ of the mixture was poured into the photometer test tube and the other tube with distilled water and the reading from the meter was looked into the sulphate table for the equivalent. (Wavelength $\lambda$ $=520 \mathrm{~mm}$ ).

Tests for silica: Silicon in the form of silica is one of the earth's abundant elements. Silicon is found widely in natural water as soluble silicate. Silica and silicate do not normally because any problem in water intended for domestic consumption. However the presence is undesirable in water used in variety of industrial application as it forms hard scale in equipment.

Procedure: $50 \mathrm{ml}$ of water sample was poured in to a beaker, followed carefully by adding $1.5 \mathrm{ml}$ of oxalic acid, $2 \mathrm{ml}$ of ammonia molybdate and $4 \mathrm{ml}$ of tretra-oxo-sulphate (IV) acid (mixed in the ratio 4,1 , that is $200 \mathrm{ml}$ of concentration. Tretra-oxo-sulphate (IV) acid was diluted with $50 \mathrm{ml}$ of distilled water), then $10 \mathrm{ml}$ of the sample was poured into test tube (Photometer test tube) and was placed inside the beam of the photometer. And wavelength was $640 \mathrm{~mm}$. The silica equivalent gotten from the meter is used to trace and checked in silica table.

\section{Test for $\mathrm{pH}$}

The sample water provided has its $\mathrm{pH}$. Where the $\mathrm{pH}$ indicates the alkalinity or acidity of any material, so the test is needed to establish these parameters.

Procedure: $50 \mathrm{ml}$ of water sample was poured into a beaker, followed by adding ten (10) drops of Bromothymol blue indicator, then the $\mathrm{pH}$ meter was dipped in to it, and the reading was taken from the meter.

Test for turbidity: Turbidity is a measure of how much material is suspended in a body of water. Clear water means low turbidity and cloudy water means high turbidity. Turbidity is caused by suspension been produced when solid is dispersed in water.

Procedure: The water sample was thoroughly shacked, and before pouring $10 \mathrm{ml}$ of it in the turbidity meter sample tube (cell). The meter was switched on and the reading was taken. 


\section{Results and discussion}

The results obtained during the course of this study were presented and discussed as follows.

\section{Qualitative analysis results}

From (Table 4), it was analyzed that the raw water $(18.00 \mathrm{ml})$ and treated water $(38.00 \mathrm{ml})$ which fall within the WHO standard of drinking water whereby the highest desirable level is $150 \mathrm{ml}$ and maximum possible level is $200 \mathrm{ml}$. Hard water may be considered as none health hazard. In fact, the National Research Council (NRC) states that hard drinking water generally contributes a small amount of calcium and magnesium to human dietary needs. Drinking alkaline water helps people with acidosis (increase acid $\mathrm{pH}$ value in the blood and other tissue). Acidosis increases the risk for developing chronic disorder and produces a variety of symptoms, such as headaches, nausea, diarrhea, and more.

Table 4 Qualitative analysis test for alkalinity $\left(\mathrm{CaCO}_{3}\right)$

\begin{tabular}{llll}
\hline Sample and reagent & Quality & \multicolumn{2}{l}{ Qualitative analysis } \\
\hline & & Raw water & Treated water \\
\hline Sample water $(\mathrm{ml})$ & 50 & 38 & 40 \\
Butter Solution $(\mathrm{ml})$ & 3 & 2 & 2 \\
$\mathrm{H}_{2} \mathrm{SO}_{4}$ (mol/liter) & 0.01 & - & - \\
$\mathrm{CaCO}_{3}(\mathrm{ml})$ & 150 & - & 120
\end{tabular}

From (Table 5), the qualitative analysis on raw and treated water falls within the WHO standard whereby the maximum possible level is $150.00 \mathrm{ml}$. In the case where the alkaline water is at high desirable level, this can be control using alkaline water purifier.

Table 5 Qualitative analysis test for Chloride $(\mathrm{Cl})$

\begin{tabular}{llll}
\hline Sample and reagent & Quality & \multicolumn{2}{l}{ Qualitative analysis } \\
& & Raw water & $\begin{array}{l}\text { Treated } \\
\text { water }\end{array}$ \\
\hline Sample water $(\mathrm{ml})$ & 50 & $\mathrm{I} 7$ & $\mathrm{I} 5$ \\
Potassium dichromate $(\mathrm{ml})$ & 3 & - & - \\
$\mathrm{AgSO}_{4}(\mathrm{~mol} / \mathrm{liter})$ & $0.0 \mathrm{I}$ & - & - \\
Chlorine $\mathrm{Cl})(\mathrm{mol} / \mathrm{liter})$ & 0.05 & - & 0 \\
\hline
\end{tabular}

Chorine is corrosive and poisonous in drinking water. The contamination of water is directly related to the degree of contamination of our environment. Chlorination of drinking water was a major factor in the reduction of the mortality rates associated with waterborne pathogen. Table 6 shows that KNWTP produce healthy and safely treated water with $0.00 \mathrm{~mol} /$ liter of chlorine when compared with the WHO standard of $0.05 \mathrm{~mol} /$ liter. Therefore, it was confirmed that no trace of chlorine found in the KNWTP processing network.

Carbon (IV) oxide is a guardian of the $\mathrm{pH}$ of the blood, which is essential for survival. The carbonic acid in water can be neutralized by hydroxide ions, which would increase the $\mathrm{pH}$ of the blood when added. The primary health danger of $\mathrm{CO}_{2}$ is asphyxiation, kidney damage and frostbite. Table 7 depicts the analysis of raw and treated water concentration estimated to be $16.00 \mathrm{ml}$ and $12.00 \mathrm{ml}$ respectively, which is above the desirable level of the WHO standard equivalent. Water quality monitoring shows that nitrite is present in groundwater has $11.20-11.40(\mathrm{mg} / \mathrm{l})$ which is less or exceed the WHO drinking water limit of $11.30 \mathrm{mg} / \mathrm{l}$. Table 7 shows that the KNWTP produce drinking water with high desirable level of nitrite which could affect the health of the public consumers.

Table 6 Qualitative analysis test for Carbon (IV) oxide $\left(\mathrm{CO}_{2}\right)$ and Nitrite $\left(\mathrm{N}_{2}\right)$

\begin{tabular}{llll}
\hline Sample and reagent & Quality & \multicolumn{2}{l}{ Qualitative analysis } \\
\hline Sample water $(\mathrm{ml})$ & 50 & 16 & 12 \\
Phenolphthalein (drops) & 3 & - & - \\
$\mathrm{NaOH}(\mathrm{mol} / \mathrm{liter})$ & 0.1 & - & $0-00$ \\
$\mathrm{CO}_{2}(\mathrm{~mol} / \mathrm{liter})$ & 0.05 & - & 0.01 \\
$\mathrm{~N}_{2}(\mathrm{mg} / \mathrm{l})$ & $1 \mathrm{l} .3$ & & $1 \mathrm{I} .20-\mathrm{II}-40$ \\
\hline
\end{tabular}

Table 7 Qualitative analysis test for Iron ( $\mathrm{Fe})$

\begin{tabular}{|c|c|c|c|}
\hline \multirow[t]{2}{*}{ Sample and reagent } & \multirow[t]{2}{*}{ Quality } & \multicolumn{2}{|c|}{ Qualitative analysis } \\
\hline & & Raw water & Treated water \\
\hline Sample water (ml) & 50 & 0 & 0.01 \\
\hline $\mathrm{HCl}$ acid $(\mathrm{ml})$ & 2 & - & - \\
\hline Ammonia acetate $(\mathrm{ml})$ & 10 & - & - \\
\hline Phenolphthalein (drops) & 2 & - & - \\
\hline Distilled water (ml) & 10 & - & - \\
\hline Iron, Fe (mol/liter) & I & 0.05 & 0.01 \\
\hline
\end{tabular}

From the analysis shown in Table 8 above, the present of iron has effect on the drinking water. The water may be discolored and appear brownish and it may even contain sediment. It can also enter into water heater and can get into the laundry equipment and course stains on clothing. From Table 8, it was observed that KNWTP produce very well and safely water with only $0.01 \mathrm{~mol} /$ liter $\mathrm{Fe}$, which fall within the WHO standard of maximum possible level of $1.00 \mathrm{~mol} / \mathrm{liter} \mathrm{Fe}$.

Table 8 Qualitative analysis test for Silicon $\left(\mathrm{SiO}_{2}\right)$

\begin{tabular}{llll}
\hline Sample and reagent & Quality & \multicolumn{2}{l}{ Qualitative analysis } \\
\hline Sample water $(\mathrm{ml})$ & 50 & 0.34 & 0.12 \\
Oxalic acid $(\mathrm{mol} / \mathrm{liter})$ & $\mathrm{Raw}$ water & Treated water \\
Ammonia acetate $(\mathrm{mol} / \mathrm{liter})$ & 2 & - & - \\
Sulphuric acid $(\mathrm{mol} / \mathrm{liter})$ & 4 & - & - \\
Distilled water $(\mathrm{ml})$ & 50 & - & - \\
\hline
\end{tabular}

Silicon dioxide $\left(\mathrm{SiO}_{2}\right)$ is dietary requirement for various organisms. The mechanism of intake is currently unclear. Silicon is generally harmless when present in water, because it is naturally present in large amount. Abnormally high concentrations might limit algal growth. In terms of health effect human body contains a total amount of $1 \mathrm{~g}$ of silicon, which decreases at a later age. From (Table 9), the result shows that KNWTP produce treated water with only 0.12 $\mathrm{ml}$ of $\mathrm{SiO}_{2}$ concentration which is not harmful to the public consumers as compared with the WHO standards for drinking water. 
Table 9 Qualitative analysis test for Sulphate $\left(\mathrm{SO}_{4}\right)$

\begin{tabular}{|c|c|c|c|}
\hline \multirow[t]{2}{*}{ Sample and reagent } & \multirow[t]{2}{*}{ Quality } & \multicolumn{2}{|c|}{ Qualitative analysis } \\
\hline & & Raw water & Treated water \\
\hline Sample water (ml) & 50 & 21 & 0.12 \\
\hline $\mathrm{HCl}$ acid (mol/liter) & I & - & - \\
\hline Barium Chloride (mol/liter) & I & - & - \\
\hline Distilled water (ml) & 10 & - & - \\
\hline SO4 (mol/liter) & 0.05 & 0.02 & 0.005 \\
\hline
\end{tabular}

The existing of sulphate in drinking water is very likely to cause adverse human health effects. The results obtain from Table 10 ; indicate that the concentration of sulphate on both raw water and treated water was $0.02 \mathrm{ml}$ and $0.005 \mathrm{~mol} /$ liter respectively. The present of sulphate in drinking water with concentration above the $0.05 \mathrm{~mol} /$ liter (WHO standard) can result in a noticeable taste; the lowest taste threshold concentration for sulphate is approximately 250 $\mathrm{mg} / \mathrm{l}$ as the sodium salt. Sulfate may also contribute to the corrosion of distribution systems.

Table 10 Analytical test for $\mathrm{pH}$

\begin{tabular}{|c|c|c|c|}
\hline \multirow[t]{2}{*}{ Sample and reagent } & \multirow[t]{2}{*}{ Quality } & \multicolumn{2}{|c|}{ Qualitative analysis } \\
\hline & & Raw water & Treated water \\
\hline Sample water (ml) & 50 & 15 & 12 \\
\hline Bromothymoblue & 10 & - & - \\
\hline Turbidity & - & 15.1 & 2.24 \\
\hline Alum conc. (\%) & 10 & - & - \\
\hline $\mathrm{pH}$ & 7 & 6.8 & 6.8 \\
\hline
\end{tabular}

From (Table 11), the turbidity value was reasonable and closed values even though it does not fall within the WHO acceptable range. It is important to look at the $\mathrm{pH}$ values of 6.80 from (Table 11), because $\mathrm{pH}$ plays an important role when alum is used for coagulation and the solubility of aluminium species in water is $\mathrm{pH}$ dependent. However, optimum coagulation occur when negatively charged forms of alum predominate which occur when the $\mathrm{pH}$ is between 6.0-8.0. So this $\mathrm{pH}$ values obtained implies that an excessive coagulant over dosing was made at the KNWTP. The values of $\mathrm{pH}$ to be slightly acidity and that of the turbidity did not falls within the range of WHO standard for drinking water. Another chemical called lime can be added to neutralize the acidity of the water.

Table II Routine analytical test for quality control

\begin{tabular}{llll}
\hline Parameter & Quality & Raw water & Treated water \\
\hline Turbidity $(\mathrm{NTU})$ & 20 & 15.1 & 2.24 \\
$\mathrm{pH}$ value & 7 & 6.8 & 6.8 \\
Chloride as $\mathrm{Cl}(\mathrm{ml})$ & 50 & 17.99 & 16.5 \\
Nitrate as $\mathrm{N}(\mathrm{ml})$ & 20 & 0.25 & 0.16 \\
Total alkalinity $\left(\mathrm{CaCO}_{3}\right)$ & 50 & 12 & 12 \\
Total hardness $\left(\mathrm{CaCO}_{3}\right)$ & 50 & 18 & 38 \\
Total iron $(\mathrm{Fe})\left(\mathrm{mol}^{\prime} /\right.$ iter $)$ & 50 & 0 & 0.01 \\
Calcium $(\mathrm{ml})$ & 50 & 16 & 36 \\
Silicon $(\mathrm{SiO})(\mathrm{mol} /$ liter $)$ & 50 & 0.34 & 0.12 \\
Sulphate $\left(\mathrm{SO}_{4}\right)(\mathrm{mol} /$ liter $)$ & 50 & 21 & 0.12 \\
Free carbon & 50 & 16 & 12 \\
\hline
\end{tabular}

\section{Quality control, KNWTP central laboratory routine} sample test

Table 12 represents the detail routine analysis for quality control test carried out for the raw water and treated water in the KNWTP processes. It was observed that the sulphate present in the raw water is very high $(21.0 \mathrm{~mol} / \mathrm{liter})$ when compared with the treated water $(0.12$ $\mathrm{mol} /$ liter). Likewise the silicon concentrations for the raw and treated water were respectively 0.34 and $0.12 \mathrm{~mol} /$ liter.

Table 12 Comparison of qualitative analysis results with the WHO standards

\begin{tabular}{lllll}
\hline Parameter & \multicolumn{2}{l}{ Qualitative analysis } & WHO highest & WHO maximum possible level \\
\cline { 2 - 3 } & Raw water & Treated water & desirable level & \\
\hline pH value & 6.8 & 6.28 & $7.0-8.5$ & $6.5-9.2$ \\
Turbidity (NTU) & 15.1 & 2.24 & 5 & 25 \\
Chloride (mg) & 17.99 & 0 & 200 & 600 \\
Nitrite (mol/liter) & 0.25 & 0.16 & 0.5 & 0.1 I \\
Carbon (IV) oxide (mg/l) & 16 & 12 & 7 & 9.5 \\
Alkalinity (pH) & 38 & 40 & - & 150 \\
Hardness (ml) & 18 & 38 & 150 & 200 \\
Iron (Fe) (mol/liter) & 0 & 0.01 & 0.1 & 1 \\
Silica (mol/liter) & 0.34 & 0.12 & - & 40 \\
Sulphate (mol/liter) & 21 & 0.12 & 200 & 400 \\
\hline
\end{tabular}

Comparison of analytical raw water and treated water with WHO standards

Table 13 depicts the detail control test carried out at the KNWTP on the daily routine basis and at specific time intervals of $30-60$ minutes. In other to deduce a reasonable conclusion, there is the need to compare the result values of with the WHO and NIS standards. 
The deductions from this comparison provide a proper determination of the effect of ozone in the KNWTP plant and their chemical concentration. Considerations were given to the chemical used as coagulant during the water treatment process because it plays a role in determining the $\mathrm{pH}$ of the water. The coagulant which were being used in the KNWTP is aluminium sulphate (because of it trivalent ion which will give an effective charge neutralization). When it is use as coagulant the water is expected to have a $\mathrm{pH}$ range of 5.5 -7.8. In accordance with WHO and National standards for drinking water, the maximum permissible level of suspended particle (turbidity) that is safe for consumption is $0-5.0 \mathrm{NTU}$ with a $\mathrm{pH}$ range of 6.5-8.5 (NIS,2007). Having established these facts, it was used as the basis for the evaluation and comparison of their performing so as to know whether these results fall within the expected range of $\mathrm{pH}$ and turbidity. From (Table 13), it was observed that there is a great reduction in the amount of suspended particle, but the $\mathrm{pH}$ of raw water remains the same even after the addition of coagulant, this was due to the fact that the $\mathrm{pH}$ meter used has less precision. More so, the table show that the $\mathrm{pH}$, turbidity, nitrite, total alkalinity, total hardness, total iron, calcium, silica, sulphate, and free-carbon of raw and treated water was used to determine the effectiveness of the water by comparing it with a WHO standard.

\section{Conclusion}

Within the limit of experimental error it was observed that the treatment operations of the Kaduna North Water Works Treatment Plant (KNWTP) is within the acceptable range of World health organization (WHO) standard for healthy drinking water, because most of the evaluating parameters were within the acceptable range. However, some parameters such as carbon (IV) oxide concentration of the raw water and treated water of about $16.00 \mathrm{ml}$ and $12.00 \mathrm{ml}$ respectively, while that of nitrite was about $0.25 \mathrm{~mol} / \mathrm{liter}$ and $0.16 \mathrm{~mol} /$ liter respectively, in which both values fall above the WHO standard for drinking water. However, these identified chemical contents may affect the health of the consumers as well as cause damages to the KNWTP process equipments and pipeline networks of the water to various distribution points. In summary, we were able to establish the aim of tracing the effects of ozone concentration in KNWTP.

\section{Recommendations}

The following recommendation should be considered for optimal operating and healthy treated water products,

i. Latest and adequate laboratory equipments should be provided such as digital $\mathrm{pH}$ meter to replace the old meter using (Lovibond comparator $\mathrm{pH}$ meter).

ii. Good practice and excellent records of all process activities should be instituted in order to ensured share knowledge and experience for the future.

iii. The operators should not be relying exclusively on past practice, because it may not be adequate for the systems, since the control tests are carried out on daily routine bases while the plant is in continues operations as well.

iv. Since ozone is a highly corrosive gas, all materials need must be resistance to oxidation. Therefore, system components, including the tubing, diffuser, insulator, conductors, unit casing, and water container need to be ozone resistant. In addition, the system should operate on an AC electric current to generate the corona discharge. As a result, all materials must be in compliance with WHO safety standards.

\section{Acknowledgements}

None.

\section{Conflict of interest}

The author declares no conflict of interest.

\section{References}

1. Marian Fierro. Atmospheric inversions that trap the pollutants near the ground. 1999;104(42):1350-1357.

2. Yusuf A, Warsito A, Syakur I, et al. Final Task, Department of Electrical Engineering, Faculty of Engineering. Diponegoro University, Indonesi, 2008.

3. Chapman BN. Glow Discharge Processes. New York: John Willey and Sons; $1990.133 \mathrm{p}$.

4. Sillman S, Logan JA, Wofsy SC. The sensitivity of ozone to nitrogen oxides and hydrocarbons in regional ozone episodes. Journal of Geophysical Research. 1990;95:1837-1851

5. Mickley B. The impacts of future emissions and climate on surface ozone concentrations using climate and chemical transport models. 2007;96(32):1265-1269

6. Andelin, J, John A. Analysis of the Montreal Protocol. US Congress, Office of Technology Assessment. 1988.

7. Morrisette Peter M. The Evolution of Policy Responses to Stratospheric Ozone Depletion. Natural Resources Journal. 1995;29:793-820.

8. Haigh JD, Winning AR, Toumi R, et al. An influence of solar spectral variations on radiative forcing of climate. Nature. 2010;467(7316):696699.

9. Bader H, Hoigené J. Determination of Ozone in Water by the Indigo Method. Water Research. 2013;15:449-456.

10. Ademoroti CMA. Pollution by Heavy Metals in the Environment. Ibadan Nigeria: Foludec Press Limited; 1996. 54 p.

11. WHO. World Health Organization International Health and safety standards guide. 2016.

12. Nikanorov A, Brazhnikova V. Types and Properties of Water, Water Chemical Composition of Rivers, Lakes and wetlands. EOLSS, USSR. 1978.

13. KNWTP Malali. Kaduna North Water Treatment Plant standard operating manual procedure. Kaduna. 2016. p. 64-1197.

14. Goorden K, Russell W. The Sludge in water as drawn off on an intermittent basis from these concentrators. 1974;97(45):567-568.

15. Kawamura S. Integrated Design and Operation of Water Treatment Facilities. New York; 2000. p. 74-5.

16. Puckorius PR. Ozone use in cooling tower systems - current guidelines. Where it works, Ozone science and engineering. 1993. 15(1):81-93.

17. Andreasson P, Troselius L. The corrosion properties of stainless steels and titanium in bleach plants. Korrosionsinstitutet. 1995. 25 p.

18. Kashcheeva TP, Sologub LV, Gadasina LY. Pitting corrosion of equipment for catalytic final purification of effluent with ozone. Protection of metals. 1981;17(21):61-162.

19. Horváth M, Bilitzky L, Hüttner LK. Budapest, Elsevier J. Ozone. 1985. $350: 16$. 
20. Brown BE, Duquette DJ. A review of the effects of dissolved ozone on the corrosion behavior of metals and materials. In Corrosion 94. Baltimore. 1994. 486:19.

21. Rice RG, Wilkes JF. Fundamental aspects of ozone chemistry in recirculating cooling water systems. In Corrosion 91, NACE, Cincinnati. 1991;205:43.

22. Matsudaira M, Suzuki M, Sato Y. Dissolved ozone effects on corrosion of metals in water. Materials Performance. 1981;20(11):55-56.

23. Sato Y, Suzuki M, Matsudaira M. Dissolved ozone effect on corrosion of metals in water. Boshoku Gijutsu. 1982;31(5):319-324.

24. Madronich S. Implications of recent total atmospheric ozone measurements for biologically active ultraviolet radiation reaching the Earth's surface. Geophysical Research Letters. 1992;19(1):37-40.

25. Guenther AC, Hewitt D Erickson, R Fall, et al. A global model of natura volatile organic compound emissions. J Geophys Res. 1995;100(5):88738892.

26. Lin CYC, Jacob DJ, Fiore A. Trends in exceedances of the ozone air quality standard in the continental United States 1980-1998. Atmospheric Environment. 2001;35(19):3217-3228.
27. Prather MR, Derwent D, Ehhalt $\mathrm{P}$, et al. Other tracer gases and atmospheric chemistry. In:Climate Change. UK: Cambridge University Press; p. 73-126.

28. Guenther AB, Baugh G, Brasseur J, et al. Isoprene emission estimates and uncertainties for the Central African EXPRESSO study domain. $J$ Geophys Res. 1999;104(D23):30625-30639.

29. Manual guide CDU1 KRPC. Kaduna Refinery and Petrochemical Company. Manual guide on the Crude Distillation Unit 1. 2005. p. 15789

30. Chiyoda A. A chemical engineering and construction company limited: A process manual. 1989.

31. Smith W. Principles of Ozone Generation. Australia: Watertec Engineering Pty Ltd; 2011.

32. Environmental Protection Agency. Drinking Water Treatment. USA: Prentice-Hall Book Press Inc; 2004. p. 54-78. 